\title{
The Effect of Chemoradiotherapy at Gastric Cancer on Pancreatic Enzymes and Pancreas Volume
}

\author{
Mustafa KANDAZ, O. Cem GULER, Adnan YONEY \\ Karadeniz Technical University, Faculty of Medicine, Department of Radiation Oncology, Trabzon, TURKEY
}

\begin{abstract}
Post-operative chemoradiotherapy is one of the therapeutic approaches for operated gastric cancer. During radiotherapy planning, pancreas has not been accepted as a critical organ until now, thus toxicity to pancreas has not been considered. In our prospective study, serum pancreatic enzyme levels and pancreatic volume after RT is investigated. Seventy-one patients with gastric cancer were evaluated adjuvant chemoradiotherapy. Mean pancreas volume, mean pancreas radiotherapy dose and V5, V10, V20 and V40 values were calculated. Fasting blood glucose, insulin, amylase and glycosylated hemoglobin levels were evaluated before radiotherapy and re-evaluated at the end of radiotherapy, at 1th, 3rd, 6th and 12th months after radiotherapy. Pancreas volume was evaluated before radiotherapy and re-evaluated at 12th month after radiotherapy. Before the initiation, after the first session and at the 1th, 3th, 6th and 12th months of radiotherapy, difference between serum Fasting blood glucose $(p=0.179)$, insulin $(p=0.296)$, HbA1c $(p=0.468)$ and amylase levels $(p=0.069)$ levels were not statistically significant but there is statistically significant decrease in pancreatic volume after treatment $(p=0.002)$. Postoperative chemoradiotherapy is able to prolong survival and decrease recurrence in operated gastric cancer patients. In our prospective study, we could not identify any statistically significant finding related to pancreatic toxicity or its presentation on biochemical parameters except pancreas atrophy in one-year period. Although, there was not any self-reported diabetes mellitus at early period it, follow-up needed for late toxicity.
\end{abstract}

Keywords: Chemoradiotherapy, Gastric cancer, Pancreatic enzymes, Pancreas volume

\section{ÖZET}

\section{Mide Kanserinde Kemoradyoterapinin Pankreas Hacmi ve Pankreas Enzimleri Üzerine Etkisi}

Post-operatif kemoradyoterapi, ameliyat edilen mide kanseri için terapötik yaklaşımlardan biridir. Radyoterapi planlaması sırasında şimdiye kadar pankreas kritik bir organ olarak kabul edilmemiştir, bu nedenle pankreas toksisitesi dikkate alınmamıştır. Prospektif çalışmamızda, radyoterapi sonrası serum pankreatik enzim düzeyleri ve pankreas hacmi araştırılmıştır. Adjuvan kemoradyoterapi uygulanan 71 mide kanserli hasta değerlendirildi. Ortalama pankreas hacmi, ortalama pankreas radyoterapi dozu ve V5, V10, V20 ve V40 değerleri hesaplandı. Açlık kan şekeri, insülin, amilaz ve glikolize hemoglobin düzeyleri radyoterapi öncesi değerlendirildi ve radyoterapi bitiminde, radyoterapiden sonra 1, 3, 6. ve 12. aylarda yeniden değerlendirildi. Pankreas hacmi radyoterapi öncesi değerlendirildi ve radyoterapiden sonraki 12. ayda yeniden değerlendirildi. Radyoterapi öncesi, radyoterapi bitiminde, radyoterapiden sonra 1, 3, 6 . ve 12. aylarda serum açlık kan glikozu ( $p=0.179)$, insülin $(p=0.296), \mathrm{HbA1c}(p=0.468)$ ve amilaz düzeyleri istatistiksel olarak anlamlı değildi $(p=0.069)$, ancak tedavi sonrası pankreas hacminde istatistiksel olarak anlamlı bir azalma vardı ( $p=0.002)$. Postoperatif kemoradyoterapi ameliyat edilen mide kanserli hastalarda sağkalımı uzatmakta ve rekürrensi azaltabilmektedir. Prospektif çalışmamızda, bir ylllık periyotta pankreas atrofisi haricinde pankreatik toksisite veya biyokimyasal parametreler üzerine istatistiksel olarak anlamlı bir bulgu tespit edemedik. Erken dönemde herhangi bir diabetes mellitus rapor edilmemesine rağmen, geç toksisite için takibi gereklidir.

Anahtar Kelimeler: Kemoradyoterapi, Gastrik kanser, Pankreatik enzimler, Pankreas hacmi 


\section{INTRODUCTION}

Gastric cancer is the fourth most common malignancy, ${ }^{1}$ being the third most common cause of cancer mortality around the worldwide. ${ }^{2}$ Treatment for gastric cancer is categorized as curative (tumor resection and lymphadenectomy) or palliative. Gastric cancer with locally advanced disease, chemoradiotherapy (CRT), chemotherapy (CT) alone or radiotherapy (RT) alone are main adjuvant treatment options. Surgical treatment alone causes high recurrence rates. ${ }^{3}$ Adjuvant CRT has been demonstrated to increase relapse-free survival (RFS) and overall survival (OS) significantly. ${ }^{4}$ The Intergroup 0116 (INT-0116) trial, the largest phase III trial comparing CRT versus observation, showed that adjuvant CRT prolonged OS and RFS. ${ }^{5,6}$

Based on these data, standard dose of RT for gastric cancer is usually 45-50.4 Gy (in the absence of residual disease), $1.8 \mathrm{~Gy}$ per fraction. ${ }^{7}$ Multi-agent CT with 5-fluorouracil and calcium folinate is the most frequently used regimen, although other agents such as capecitabine are being used in an increasing fashion. ${ }^{8}$

RT is inevitably associated with side effects and the normal tissue toxicity is the major impediment to administer effective radiation dose. Improved RT techniques are likely to deliver radiation dose more accurately and reduce radiation toxicity significantly.

In RT guidelines, spinal cord, heart, lung, liver and kidney are stated to be the organs at risk, and dose restrictions for each of them are defined. On the other hand, there is no information about pancreas even it's effected by most of the RT dose since it's in close neighborhood of stomach and dose levels which may adversely effect the pancreatic function are not defined.

In this study, patients who referred to our clinic with gastric cancer and underwent RT were evaluated prospectively and effects of pancreatic RT doses and outcomes were studied. The association among plasma diabetic biomarkers fasting blood glucose (FBG), glycosylated hemoglobin (HbA1c), insulin and amylase, pancreas volume and CRT was determined in this study.

\section{PATIENTS AND METHODS}

Patients who were diagnosed as gastric cancer and referred to our clinic for adjuvant CRT were included in this prospective study, Diabetic patients were excluded from study. For investigating the effects of RT over pancreas, FBG (mg/dl), insulin (uIU/ $\mathrm{mL})$, amylase (U/L) and HbA1c (\%) levels were evaluated at the initiation. On the treatment planning, pancreas was contoured among the organs at risk. All the patients had computerized tomography (CT) scans at the control visit in 12th month after RT and pancreas was contoured again to evaluate the difference. Mean pancreatic dose and the pancreatic volume that received 5 Gy (V5), 10 Gy (V10), 20 Gy (V20) and 40 Gy (V40) values were calculated. FBG, insulin, amylase and $\mathrm{HbA1c}$ levels were evaluated before RT and re-evaluated at the end of RT and at 1th, 3rd, 6th and 12th months of RT. Pancreas volume were evaluated before RT and re-evaluated 12 months after RT. This study was approved by intuitional ethical committee, project no: 2015/9.

\section{Patients Characteristics}

75 patients were examined in total and all the patients had stage I-IIIC gastric cancer. There were $23(32 \%)$ females and 48 (68\%) males and female to male ratio was $1 / 1.7$. Mean age at presentation was $55 \pm 9.2$ (36-75). Of those tumors, 10 (14\%) were located in the cardia, $31(44 \%)$ in the corpus, $24(34 \%)$ in the antrum and $6(8 \%)$ in the pylorus. The most common histologic subtype was adenocarcinoma (87\%), followed by signet ring cell carcinoma (13\%). The surgical margin was negative in $53(75 \%)$ and positive in $18(25 \%)$ cases. In terms of pathological grade, grade I was seen in 18 (25\%), grade II was seen in 19 (27\%) and grade III was seen in $34(48 \%)$ patients respectively. Total excision was performed in $42(59 \%)$ patients and subtotal excision was performed in $29(41 \%)$ patients. 20 (28\%) patients had undergone D1 dissection and $51(73 \%)$ patients had D2 dissection. In terms of pathological stage: $2(3 \%)$ patients were diagnosed as stage IA, $2(3 \%)$ patients as stage IB, $6(8 \%)$ patients as stage IIA, $13(18 \%)$ patients as stage IIB, $19(27 \%)$ patients as stage IIIA, 13 (18\%) patients as stage IIIB, and $16(23 \%)$ patients 
International Journal of Hematology and Oncology

Table 1. Patient characteristics and pancreas doses

\begin{tabular}{|c|c|c|c|c|c|c|}
\hline & n (\%) & $\begin{array}{l}\text { Pancreas Mean } \\
\text { Dose }\end{array}$ & Pancreas V5 & Pancreas V10 & Pancreas V20 & Pancreas V40 \\
\hline General & 71 & $\begin{array}{l}4456.88 \pm 204.55 \\
(3760-4767)\end{array}$ & $99.96 \pm 0.35$ & $99.85 \pm 0.92$ & $99.27 \pm 3.34$ & $94.86 \pm 10.51$ \\
\hline \multicolumn{7}{|l|}{ Sex } \\
\hline Female & $23(32)$ & $\begin{array}{l}443.33 \pm 235.21 \\
(3760-4767)\end{array}$ & $99.94 \pm 0.43$ & $99.77 \pm 1.11$ & $98.92 \pm 4.03$ & $93.81 \pm 12.10$ \\
\hline Male & $48(68)$ & $\begin{array}{l}4503.70 \pm 105.57 \\
(4246-4676)\end{array}$ & 100.0 & 100.0 & 100.0 & $97.04 \pm 5.59$ \\
\hline \multicolumn{7}{|l|}{ Anatomical Site } \\
\hline Cardia & $10(14)$ & $\begin{array}{l}4522.86 \pm 117.45 \\
(4358-4700)\end{array}$ & 100.0 & 100.0 & 100.0 & $97.57 \pm 4.79$ \\
\hline Corpus & $31(44)$ & $\begin{array}{l}4508.68 \pm 167.23 \\
(4021-4676)\end{array}$ & 100.0 & 100.0 & 100.0 & $94.68 \pm 10.75$ \\
\hline Antrum & $24(34)$ & $\begin{array}{l}4417.48 \pm 229.94 \\
(3760-4630)\end{array}$ & 100.0 & 100.0 & $98.81 \pm 4.81$ & $95.57 \pm 11.26$ \\
\hline Pylorus & $6(8)$ & $\begin{array}{l}4503.33 \pm 66.51 \\
(4436-4569)\end{array}$ & 100.0 & 100.0 & 100.0 & $98.67 \pm 1.52$ \\
\hline \multicolumn{7}{|l|}{ T Stage } \\
\hline T1 & $3(4)$ & $\begin{array}{l}4338.33 \pm 312.98 \\
(3977-4525)\end{array}$ & $99.0 \pm 1.73$ & $98.33 \pm 2.88$ & $96.67 \pm 5.77$ & $91.33 \pm 12.50$ \\
\hline T2 & $4(6)$ & $\begin{array}{l}4271.67 \pm 490.57 \\
(3786-4767)\end{array}$ & 100.0 & $98.0 \pm 3.46$ & $95.0 \pm 8.66$ & $89.0 \pm 19.05$ \\
\hline T3 & $31(44)$ & $\begin{array}{l}4493.43 \pm 133.81 \\
(4092-4700)\end{array}$ & 100.0 & 100.0 & $99.93 \pm .036$ & $97.73 \pm 5.43$ \\
\hline T4 & $33(46)$ & $\begin{array}{l}4478.25 \pm 178.96 \\
(3847-4686)\end{array}$ & 100.0 & 100.0 & $99.91 \pm 0.53$ & $94.50 \pm 11.78$ \\
\hline \multicolumn{7}{|l|}{ N Stage } \\
\hline NO & $9(13)$ & $\begin{array}{l}4423.22 \pm 211.08 \\
(3977-4700)\end{array}$ & $99.67 \pm 1.00$ & $99.44 \pm 1.66$ & $98.89 \pm 3.33$ & $93.56 \pm 8.17$ \\
\hline $\mathrm{N} 1$ & $17(24)$ & $\begin{array}{l}4419.13 \pm 257.10 \\
(3786-4657)\end{array}$ & 100.0 & $99.63 \pm 1.50$ & $98.88 \pm 3.77$ & $93.25 \pm 13.34$ \\
\hline N2 & $17(24)$ & $\begin{array}{l}4511.19 \pm 147.60 \\
(4157-4676)\end{array}$ & 100.0 & 100.0 & 100.0 & $99.06 \pm 1.34$ \\
\hline N3 & 28 (39) & $\begin{array}{l}4490.48 \pm 152.38 \\
(4021-4686)\end{array}$ & 100.0 & 100.0 & $99.93 \pm 0.38$ & $95.48 \pm 10.76$ \\
\hline \multicolumn{7}{|l|}{ Stage } \\
\hline $\mid A$ & $2(3)$ & 3786.0 & 100.0 & 94.0 & 85.0 & 67.0 \\
\hline IB & $2(3)$ & 4413.0 & 100.0 & 99.69 & 99.19 & 90.81 \\
\hline$\| \mathrm{A}$ & $6(8)$ & $\begin{array}{l}4478.11 \pm 74.07 \\
(4406-4643)\end{array}$ & 100.0 & 100.0 & $97.56 \pm 7.33$ & $93.44 \pm 12.69$ \\
\hline$\| \mathrm{B}$ & $13(18)$ & $\begin{array}{l}4405.56 \pm 281.44 \\
(3760-4686)\end{array}$ & 100.0 & 100.0 & $99.88 \pm 0.48$ & $95.65 \pm 7.19$ \\
\hline$\| I A$ & $19(27)$ & $\begin{array}{l}4541.47 \pm 117.39 \\
(4200-4700)\end{array}$ & 100.0 & 100.0 & 100.0 & $97.73 \pm 6.20$ \\
\hline$\| I B$ & $13(18)$ & $\begin{array}{l}4457.24 \pm 157.03 \\
(4092-4657)\end{array}$ & 100.0 & 100.0 & 100.0 & $98.33 \pm 2.06$ \\
\hline IIIC & $16(23)$ & $\begin{array}{l}4428.75 \pm 263.68 \\
(3847-4767)\end{array}$ & 100.0 & 100.0 & 100.0 & $99.25 \pm 2.45$ \\
\hline \multicolumn{7}{|l|}{ Histology } \\
\hline Adenocarcinoma & $62(87)$ & $\begin{array}{l}4462.13 \pm 201.61 \\
(3786-4767)\end{array}$ & $99.95 \pm 0.40$ & $99.80 \pm 1.03$ & $99.46 \pm 2.41$ & $94.77 \pm 10.72$ \\
\hline Signet Cell & $9(13)$ & $\begin{array}{l}4504.83 \pm 106.38 \\
(4262-4686)\end{array}$ & 100.0 & 100.0 & 100.0 & $99.17 \pm 2.12$ \\
\hline
\end{tabular}


International Journal of Hematology and Oncology

\begin{tabular}{|c|c|c|c|c|c|c|}
\hline & n (\%) & $\begin{array}{l}\text { Pancreas Mean } \\
\text { Dose }\end{array}$ & Pancreas V5 & Pancreas V10 & Pancreas V20 & Pancreas V40 \\
\hline \multicolumn{7}{|l|}{ RT Dose } \\
\hline 45 Gy & $53(75)$ & $\begin{array}{l}4457.16 \pm 218.20 \\
(3760-4700)\end{array}$ & $99.94 \pm 0.42$ & $99.78 \pm 1.09$ & $98.96 \pm 3.95$ & $95.64 \pm 9.72$ \\
\hline 50.4 Gy & $16(23)$ & $\begin{array}{l}4488.88 \pm 165.87 \\
(4021-4686)\end{array}$ & 100.0 & 100.0 & 100.0 & $92.31 \pm 12.93$ \\
\hline 54 Gy & $2(3)$ & $\begin{array}{l}4483.50 \pm 400.93 \\
(4200-4767)\end{array}$ & 100.0 & 100.0 & 100.0 & $88.00 \pm 16.97$ \\
\hline \multicolumn{7}{|l|}{ Grade } \\
\hline । & $18(25)$ & $\begin{array}{l}4468.31 \pm 123.47 \\
(4157-4657)\end{array}$ & 100.0 & $99.83 \pm 1.01$ & $99.49 \pm 2.5$ & $94.11 \pm 12.27$ \\
\hline ॥ & $19(27)$ & $\begin{array}{l}4468.69 \pm 209.94 \\
(3786-4700)\end{array}$ & 100.0 & 100.0 & 100.0 & $97.92 \pm 3.7$ \\
\hline III & $34(48)$ & $\begin{array}{l}4560.08 \pm 109.07 \\
(4383-4676)\end{array}$ & 100.0 & 100.0 & 100.0 & $98.92 \pm 2.25$ \\
\hline \multicolumn{7}{|c|}{ Surgical margins } \\
\hline Negative & $53(75)$ & 4447.55 & 99.94 & 99.78 & 99.41 & 94.25 \\
\hline Positive & $18(25)$ & 4536.00 & 100.0 & 100.0 & 100.0 & 99.41 \\
\hline \multicolumn{7}{|l|}{ Dissection } \\
\hline D1 & $20(28)$ & $\begin{array}{l}4446.06 \pm 216.08 \\
(3847-4676)\end{array}$ & $99.83 \pm 0.70$ & $99.72 \pm 1.17$ & $99.28 \pm 2.42$ & $94.72 \pm 10.76$ \\
\hline D2 & $51(73)$ & $\begin{array}{l}4478.16 \pm 179.04 \\
(3786-4767)\end{array}$ & 100.0 & $99.88 \pm 0.84$ & $99.66 \pm 2.13$ & $95.84 \pm 9.66$ \\
\hline \multicolumn{7}{|l|}{ Surgery } \\
\hline Total & $42(59)$ & $\begin{array}{l}4498.20 \pm 163.57 \\
(3786-4700)\end{array}$ & 100.0 & $99.85 \pm 0.93$ & $99.59 \pm 2.35$ & $97.05 \pm 7.40$ \\
\hline Subtotal & $29(41)$ & $\begin{array}{l}4426.33 \pm 216.95 \\
(3847-4767)\end{array}$ & $99.89 \pm 0.57$ & $99.81 \pm 0.96$ & $99.52 \pm 1.98$ & $93.26 \pm 12.61$ \\
\hline \multicolumn{7}{|l|}{ Chemotherapy } \\
\hline FUFA & $64(90)$ & $\begin{array}{l}4454.45 \pm 215.00 \\
(3760-4767)\end{array}$ & $99.95 \pm 0.38$ & $99.82 \pm 0.98$ & $99.16 \pm 3.57$ & $94.94 \pm 10.95$ \\
\hline Capecitabine & $7(10)$ & $\begin{array}{l}4480.67 \pm 125.10 \\
(4246-4604)\end{array}$ & 100.0 & 100.0 & 100.0 & $94.67 \pm 8.09$ \\
\hline
\end{tabular}

as stage IIIC. 53 patients (75\%) were treated with $45 \mathrm{~Gy}, 16$ patients $(23 \%)$ were treated with $50.4 \mathrm{~Gy}$ and 2 patients (3\%) were treated 54Gy. FUFA was given to $64(90 \%)$ patients and capecitabine was given to $7(10 \%)$ patients.

Radiation planning was made with 3D-CRT and IMRT and dose-volume histogram data was available for the organs at risk including the pancreas. 71 patients were examined; mean pancreatic radiation dose was $4456.88 \mathrm{cGy}$. V5 of the pancreas had received $99.96 \%, \mathrm{~V} 10$ of the pancreas had received $99.85 \%$, V20 of the pancreas had received $99.27 \%$ and V40 of the pancreas had received $94.86 \%$. Patient characteristics and pancreas doses are summarized in Table 1.

\section{Treatment}

Three-dimensional conformal RT (3D-CRT), or Intensity-Modulated Radiation Therapy (IMRT) technique, were performed at fractions of $1.8 \mathrm{~Gy}$ daily for a total of 45-50.4-54Gy which was delivered by using 6-18 MV photons. 16 patients (23\%) were treated up to $50.4 \mathrm{~Gy}$ dose and 2 patients (3\%) treated up to 54Gy dose according of clinician's choice according to risk factors. RT field included the tumor bed/ the remaining stomach, as well as regional nodes (perigastric, celiac, local para-aortic, splenic, suprapancreatic, pancreaticoduodenal, and porta hepatic) and extended $2 \mathrm{~cm}$ beyond the proximal and distal margins of resection. CT (fluorouracil, $425 \mathrm{mg} / \mathrm{m}^{2} /$ day and leucovorin, $20 \mathrm{mg}$ / 
International Journal of Hematology and Oncology

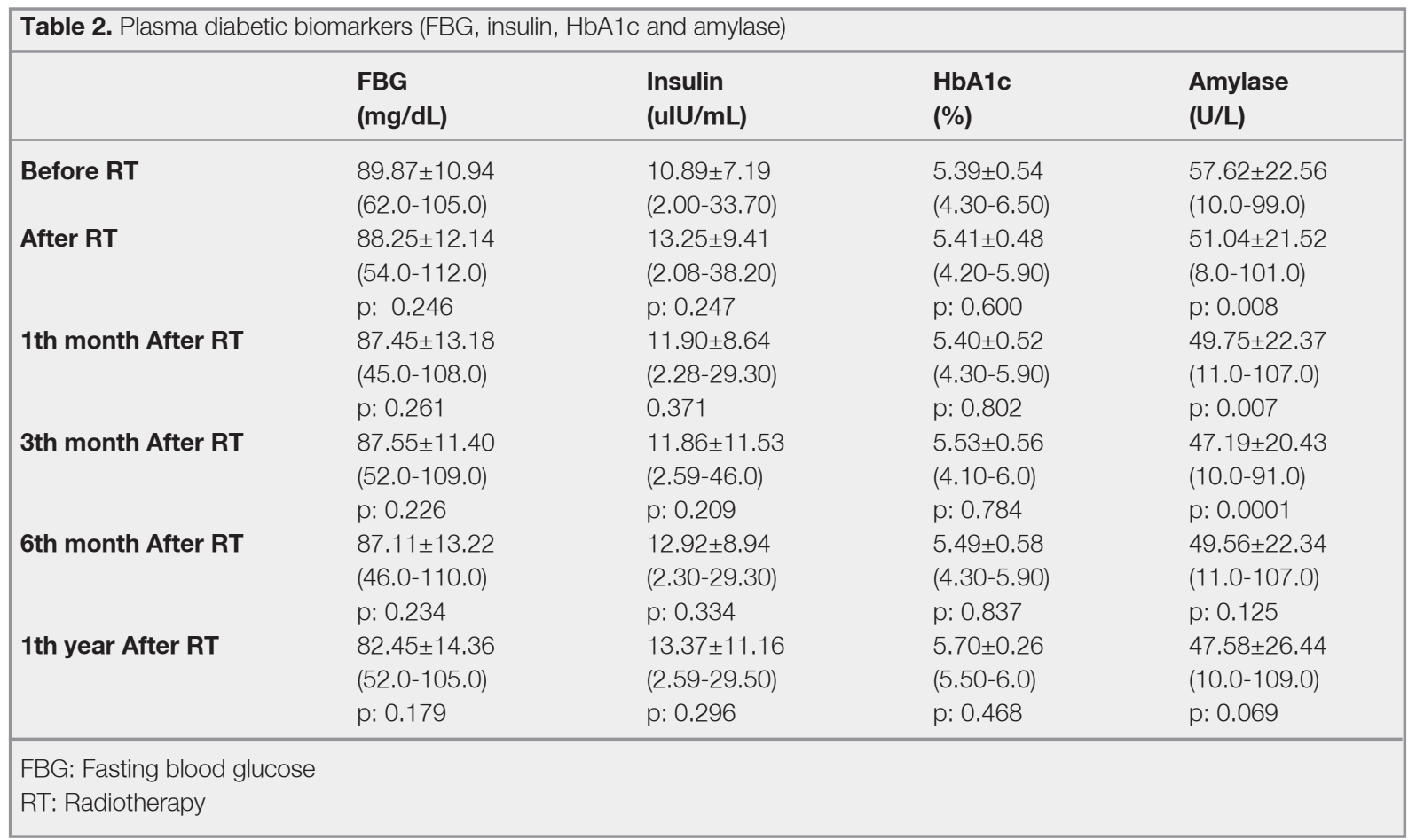

$\mathrm{m}^{2} /$ day) was initiated on day 1 and was followed by CRT 28 days after the beginning of the initial cycle of CT. The second course of CT including fluorouracil (400 $\mathrm{mg} / \mathrm{m}^{2} /$ day) and leucovo $\neg$ rine $\left(20 \mathrm{mg} / \mathrm{m}^{2} /\right.$ day) was given on the first four and the last three days of RT. Capecitabine $825 \mathrm{mg} / \mathrm{m}^{2}$ PO BID added to the therapy on days 1-5 weekly for 5 weeks. Upon the end of RT course, the first course CT scheme was carried out as adjuvant therapy throughout three months.

\section{Follow-up}

Visits to follow up were carried out at the first month after completion of RT and then three months during the first two years, after this procedure the follow up visits were applied at six months intervals. Physical examination, a complete blood count, liver function tests were repeated in each visit and thoracic and abdominal computed tomography scanning were administrated when clinically indicated. Follow-up visits continued from the initial diagnosis to the last follow-up or date of death. Statistical analysis of the data was done with SPSS Software (version 13.0 for Windows). For interaction analysis Repeated Measures test was used.

\section{RESULTS}

Normal blood levels of FBG, insulin, HbA1c and amylase were $74-106 \mathrm{mg} / \mathrm{dL},<29.1 \mathrm{uIU} / \mathrm{mL}, 4.5$ $6.0 \%$ and $28-100 \mathrm{U} / \mathrm{L}$ respectively. Before the initiation of RT, after the first session of RT and 1st, 3rd, 6th and 12th month after RT, FBG levels were $89.87 \pm 10.94 \quad(62.0-105.0), \quad 88.25 \pm 12.14(54.0$ $112.0), 87.45 \pm 13.18$ (45.0-108.0), $87.55 \pm 11.40$ $(52.0-109.0), \quad 87.11 \pm 13.22 \quad(46.0-110.0)$ and $82.45 \pm 14.36$ (52.0-105.0) respectively. Between the six measurement in terms of FBG, no statistically significant difference was seen $(\mathrm{p}=0.179)$.

Before the initiation of RT, after the first session of RT and 1st, 3rd, 6th and 12th month after RT, insulin levels were 10.89 \pm 7.19 (2.00-33.70), $13.25 \pm 9.41$ (2.08-38.20), $11.90 \pm 8.64$ (2.28-29.30), $11.86 \pm 11.53(2.59-46.0), 12.92 \pm 8.94(2.30-29.30)$ and $13.37 \pm 11.16(2.59-29.50)$ respectively. Between the six measurement in terms of insulin, no statistically significant difference was seen $(\mathrm{p}=$ 0.296).

Before the initiation of RT, after the first session of RT and 1st, 3rd, 6th and 12th month after RT, HbA1c levels were 5.39 \pm 0.54 (4.30-6.50), $5.41 \pm 0.48 \quad(4.20-5.90), \quad 5.40 \pm 0.52 \quad(4.30-5.90)$, 
Table 3. Before RT and 1th year after RT Pancreas volüme

\begin{tabular}{|c|c|c|c|}
\hline & \multicolumn{2}{|c|}{ Pancraes Volume } & \multirow[b]{2}{*}{$\mathbf{p}$} \\
\hline & Before RT & 12th month After RT & \\
\hline \multirow[t]{2}{*}{ All patients } & $55.79 \pm 21.71$ & $21.97 \pm 6.85$ & 0.0001 \\
\hline & (26.14-153.12) & $(12.46-32.41)$ & \\
\hline \multirow[t]{2}{*}{45 Gy } & $55.59 \pm 22.19$ & $21.56 \pm 6.39$ & 0.0001 \\
\hline & $(26.14-153.12)$ & $(13.84-32.41)$ & \\
\hline \multirow[t]{2}{*}{$\geq 50.4$ Gy } & $56.92 \pm 22.59$ & $22.66 \pm 8.15$ & 0.002 \\
\hline & (30.60-104.43) & (12.46-30.80) & \\
\hline
\end{tabular}

$5.53 \pm 0.56(4.10-6.0), 5.49 \pm 0.58(4.30-5.90)$ and $5.70 \pm 0.26(5.50-6.0)$ respectively. Between the six measurement in terms of $\mathrm{HbA} 1 \mathrm{c}$, no statistically significant difference was seen $(\mathrm{p}=0.468)$.

Before the initiation of RT, after the first session of RT and 1st, 3t, 6th and 12th month after RT, amylase levels were 57.62 \pm 22.56 (10.0-99.0), $51.04 \pm 21.52 \quad(8.0-101.0), \quad 49.75 \pm 22.37 \quad(11.0-$ 107.0), $47.19 \pm 20.43 \quad(10.0-91.0), \quad 49.56 \pm 22.34$ (11.0-107.0) and 47.58 \pm 26.44 (10.0-109.0) respectively. Amylase levels were decreased until 3rd month after RT (p:0.0001) but, after 1 year of RT, there was no statistically significant difference $(\mathrm{p}=$ $0.069)$.

Though temporary reduction of amylase levels occurred in most patients, RT was not pertained to a pathologic level in the early term. However none of the patients were diagnosed as diabetes mellitus at the end of the follow-up. Plasma levels of FBG, insulin, HbA1c and amylase are summarized in Table 2.

Mean pancreatic volume of all patients was found to be $55.79 \pm 21.71 \mathrm{~cm}^{3}$. A wide scope of pancreatic volume assigned from $26.14-153.12 \mathrm{~cm}^{3}$ were observed. In 45Gy RT group mean value was calculated as $55.59 \pm 22.19 \mathrm{~cm}^{3}(26.14-153.12)$ and in $\geq 50.40$ Gy RT group mean value was found to be $56.92 \pm 22.59 \mathrm{~cm}^{3}(30.60-104.43)$. All the patients had CT scans at the control visit in 12th month after RT and pancreas was contoured again to evaluate the difference. Mean pancreatic volume of all the patients was measured as $21.97 \pm 6.85 \mathrm{~cm} 3$ (12.46-32.41) ( $\mathrm{p}=0.0001)$. In 45Gy RT group, mean pancreatic volume was $21.56 \pm 6.39 \mathrm{~cm} 3$ $(13.84-32.41)(\mathrm{p}=0.0001)$ and in $\geq 50.40 \mathrm{~Gy} \mathrm{RT}$ it was $22.66 \pm 8.15 \mathrm{~cm} 3(12.46-30.80)(\mathrm{p}=0.002)$ after 1 year of RT. All the patients who underwent RT were showed a $38 \%$ reduction in pancreatic volume at first year. Volume reduction was $38 \%$ and $39 \%$ in 45 Gy group and $\geq 50.40$ Gy group respectively. These values were found to be statistically significant. Pancreas volumes were summarized in Table 3.

\section{DISCUSSION}

Gastric cancer is fourth most common malignancy around the worldwide. Mean age for gastric cancer is 65 and it peaks in the 6th and 8th decades of life. Mean age was found as 55 (36-75) in our study. Gastric cancer is more common in men with a male/female ratio of 1.5/2.9 In this study, women/ men ratio was found to be $1 / 1.7$.

Surgical resection is a mainly used technique in curative treatment for gastric cancer, additionally $30 \%-50 \%$ of the patients are able to be surgically treated with curative intent. ${ }^{10}$ Surgical treatment alone causes high recurrence rates. Distant metastases after resection or the high rates of relapse give a remarkable importance in terms of adjuvant treatment for the patients having resected gastric cancer. Adjuvant CRT has been demonstrated to increase RFS and OS significantly. Provided that gastric cancer patients live long, an opportunity of studying the radiation related late toxicity.

Pancreas as an organ at risk for radiation related to late toxicity is not examined; furthermore underlying procedure of the damage is not determined. In guidelines, spinal cord, heart, liver and kidney are defined as the organs at risk and dose restriction 
for each of them are defined. On the other hand, there is no information about pancreas even it's effected by most of the RT dose since it's in close neighborhood of stomach and dose levels which may adversely effect the pancreatic function are not defined.

Pancreas as an organ at risk for radiation related late toxicity is not studied and the underlying mechanism of the damage is not known. FBG and HbAlc levels are mandatory for the diagnosis of diabetes. Diabetes mellitus (DM) is associated with some type of cancers including liver, breast endometrial, bladder, colorectal and pancreatic cancer. ${ }^{11}$ Some prospective studies reported that determination of DM was associated with gastric cancer. ${ }^{12}$ Some studies reported pancreatic radiation toxicity as well as diabetes mellitus was higher in survivors of childhood cancers (leukemia, lymphoma, Wilm's tumor, renal tumors, neuroblastoma, soft tissue sarcoma) who had undergone upper gastrointestinal system RT. ${ }^{13}$ Relationship between gastric cancer and diabetes was shown in animal model. It was mostly related with chemical induction of carcinogenesis.14 Gemici et al. ${ }^{15}$ investigated the evaluation of late radiation induced endocrine functional disturbance of the pancreatic tissue in operated gastric cancer patients treated with adjuvant RT. In consideration of $\mathrm{HbAlc}$ and FBG, there did not emerge any difference between the control and study groups at 12th months comparing the last phase and initial levels. In our study, there was no difference between pancreatic and plasma FBG and $\mathrm{HbAlc}$ levels.

Plasma insulin levels are able to provide significant information on the function of Langerhans cells. In the study of Heijmanns et al. ${ }^{16}$ a significant decrease within insulin secretion in dogs treated with 30-35 Gy IORT. In contrast to endocrine function, exocrine function was affected too much. ${ }^{25}$ Gy IORT was determined to be safe in relation to endocrine and exocrine insufficiency. In another animal study, exocrine pancreatic insufficiency has occurred after RT and IORT. Besides, there has been no evidence of radiation damage to the islets of Langerhans. ${ }^{17}$ In our study plasma insulin levels did not altered due to the radiation damage to the islets of Langerhans.
Amylase levels have the capability of providing information about the function of acinus sacs. The enzyme content of pancreatic secretion is decreased by exposure of pancreas to radiation. The acinar cells of the pancreas are relatively sensitive to radiation and this finding has been described clearly after RT findings.18 In some studies, chronic pancreatitis was reported years after abdominal RT. ${ }^{19}$ In our study, exposure of pancreas to radiation decreases plasma amylase levels. Likewise, plasma amylase levels were associated with decreased risk of gastric cancer. In our study, decreased in plasma amylase levels was found with radiation dose of 5Gy (V5) in pancreas $(p=0.001)$. Latter doses beyond 5Gy (V10, V20 and V40) were not associated with decrease in such biochemical levels.

Djuric-Stefanovic et al.20 reported that mean volume of normal pancreas was $79.2 \mathrm{~cm}^{3}$ with a standard deviation (SD) of $24.1 \mathrm{~cm}^{3}$. The volume of the pancreas showed a range from 37.4 to $168.2 \mathrm{~cm}^{3}$ Stefanovic et al. reported an average pancreas volume of $79 \pm 24 \mathrm{~cm}^{3}$ in 220 individuals (mean age 56 years). In our study, mean pancreatic volume of all the patients was $55.79 \pm 21.71 \mathrm{~cm}^{3}$. It was observed the fact that a wide range of the pancreatic volume values from 26.14 to $153.12 \mathrm{~cm}^{3}$. Mean pancreatic volume was measured as $55.59 \pm 22.19 \mathrm{~cm}^{3}(26.14$ $153.12)$ in 45 Gy RT group and $56.92 \pm 22.59 \mathrm{~cm}^{3}$ (30.60-104.43) in $\geq 50.40$ Gy RT group.

In the study of Ahmadu-Suka et al.21 RT doseresponse relationships were observed for the damage to the pancreas as a whole, for pancreatic fibrosis and decrease in normal acinar cells. In our study, mean pancreatic volume of all the patients was measured as $21.97 \pm 6.85 \mathrm{~cm}^{3}(12.46-32.41)$. In 45 Gy RT group, mean pancreatic volume was $21.56 \pm 6.39 \mathrm{~cm}^{3}(13.84-32.41)$ and in $\geq 50.40 \mathrm{~Gy}$ RT it was $22.66 \pm 8.15 \mathrm{~cm}^{3}(12.46-30.80)$ after 1 year of RT. In conclusion, pancreatic volumes of all the patients who underwent RT showed a statistically significant decrease.

Acinar cells of the pancreas, which are more sensitive to radiation induced injury more than islet cells, decrease during gastric cancer RT. Chronic vascular injury is the main way for radiation damage such as fibrosis and atrophy. ${ }^{16}$ 


\section{Conclusion}

Postoperative CRT is able to prolong survival and decrease recurrence in operated gastric cancer patients. In our prospective study, we could not identify any statistically significant finding related to pancreatic toxicity or its presentation on biochemical parameters except pancreas atrophy in one-year period. Although, there was not any self-reported DM at early period it, follow-up needed for late toxicity.

\section{REFERENCES}

1. Jemal A, Bray F, Center MM, et al. Global cancer statistics. CA Cancer J Clin 61: 66-90, 2011.

2. Torre LA, Bray F, Siegel RL, et al. Global cancer statistics. CA Cancer J Clin 65: 87-108, 2015.

3. D'Angelica M, Gonen M, Brennan MF, et al. Patterns of initial recurrence in completely resected gastric adenocarsinoma. Ann Surg 240: 808-816, 2004.

4. Macdonald JS, Smalley SR, Benedetti J, et al. Chemoradiotherapy after surgery compared with surgery alone for adenocarsinoma of the stomach or gastroesophageal junction. $\mathrm{N}$ Engl J Med 345: 725-730, 2001.

5. Smalley SR, Benedetti JK, Haller DG, et al. Updated analysis of SWOG-directed intergroup study 0116: a phase III trial of adjuvant radiochemo $\neg$ therapy versus observation after curative gas $\rightarrow$ tric cancer resection. J Clin Oncol 30: 2327-2333, 2012.

6. Bruixola G, Segura Á, Díaz-Beveridge R, et al. Adjuvant chemoradiation in gastric cancer: long-term outcomes and prognostic factors from a single institution. Tumori 101: 517-523, 2015.

7. Illknur BG, Evrim B, Seymen B, et al. Mide karsinomlarinda poliklinik sartlarinda ameliyat sonrasi konkomitan kemoradyoterapi uygulamasi (Protokol ön sonuçlari). Türk Onkoloji Dergisi 21: 178-184, 2006.

8. Czito BG, Palta M, Willett CG. Stomach Cancer. In: Perez CA, Brady LW, Halperin EC, et al., editors. Principles and Practice of Radiation Oncology, 6th ed. Philadelphia, Lippincott Williams and Wilkins 2013: 1165-1189.

9. Hartgrink HH, Jansen EP, van Grieken NC, van de Velde CJ. Gastric cancer. Lancet 374: 477-490, 2009.

10. Macdonald JS. Role of post-operative chemo-radiation in resected gastric cancer. J Surg Oncol 90: 166-170, 2005.

11. Onitilo AA, Engel JM, Glurich I, et al. Diabetes and cancer I: risk, survival, and implications for screening. Cancer Causes Control 23: 967-981, 2012.
12. Lin SW, Freedman ND, Hollenbeck AR, et al. Prospective study of self-reported diabetes and risk of upper gastrointestinal cancers. Cancer Epidemiol Biomarkers Prev 20: 954-961, 2011.

13. Meacham LR, Sklar CA, Li S, et al. Diabetes mellitus in longterm survivors of childhood cancer. Increased risk associated with radiation therapy: a report for the childhood cancer survivor study. Arc Intern Med 169: 1381-1388, 2009.

14. Yoshizawa N, Yamaguchi H, Yamamoto M, et al. Gastric carcinogenesis by $\mathrm{N}$-methyl- $\mathrm{N}$-nitrosourea is enhanced in $\mathrm{db} / \mathrm{db}$ diabetic mice. Cancer Science 100: 1180-1185, 2009.

15. Gemici C, Sargin M, Uygur BO, et al. Risk of endocrine pancreatic insufficiency in patients receiving adjuvant chemoradiation for resected gastric cancer. Radiother Oncol 107: 195199, 2013.

16. Heijmans HJ, Mehta DM, Kleibeuker JH, et al. Intraoperative irradiation of the canine pancreas: short term effects. Radiother Oncol 29: 347-351, 1993.

17. Castro JR, Saunders WM, Quivey JM, et al. Clinical problems in radiotherapy of carcinoma of the pancreas. Am J Clin Oncol 51: 579-587,1982.

18. Zook BC, Bradley EW, Casarett GW, Rogers CC. Pathologic effects of fractionated fast neutrons or photons on the pancreas, pylorus and duodenum of dogs. Int J Radiat Oncol Biol Phys 9: 1493-1504, 1983.

19. Yamaguchi K, Nakamura K, Kimura M, et al. Intraoperative radiation enhances decline of pancreatic exocrine function after pancreatic head resection. Dig Dis Sci 45: 1084-1090, 2000.

20. Djuric-Stefanovic A, Masulovic D, Kostic J, et al. CT volumetry of normal pancreas: correlation with the pancreatic diameters measurable by the cross-sectional imaging, and relationship with the gender, age, and body constitution. Surg Radiol Anat 34: 811-817, 2012.

21. Ahmadu-Suka F, Gillette EL, Withrow SJ, et al. Pathologic response of the pancreas and duodenum to experimental intraoperative irradiation. Int J Radiat Oncol Biol Phys 14: 1197 1204, 1998.

\section{Correspondence:}

Dr. Mustafa KANDAZ

Karadeniz Teknik Üniversitesi Tip Fakultesi

Radyasyon Onkolojisi Anabilim Dali

Universite Mahallesi

TRABZON / TURKEY

Tel: (+90-462) 3775595

Cep: (+90-532) 7332909

e-mail: mkandaz61@gmail.com 